\title{
Efficacy of Bacteriophage Treatment on Pseudomonas aeruginosa Biofilms
}

By:

\begin{abstract}
Alysen Leigh Phee
A thesis submitted in conformity with the requirements

for the degree of Master of Science

Faculty of Dentistry

University of Toronto
\end{abstract}

(C) Copyright by Alysen Leigh Phee (2012) 


\title{
Efficacy of Bacteriophage Treatment on Pseudomonas aeruginosa Biofilms
}

\author{
Alysen Leigh Phee \\ Master of Science \\ Faculty of Dentistry \\ University of Toronto
}

2012

\begin{abstract}
Introduction: Bacterial viruses (phages) have been used successfully in the treatment of animal and human bacterial infections. This study examined the potential use of phage therapy against Pseudomonas aeruginosa strain PA14 biofilms in a root canal model. Methods: Part 1: 24 and 96h PA14 biofilms grown in microplates were treated with phages identified as possessing potential biofilm degrading activities and the posttreatment bacterial biomass was quantified using crystal violet staining. Part 2: 24 and 96h PA14 biofilms grown in prepared root canals of extracted human mandibular incisors were treated with phages identified with potential biofilm-degrading activities. Posttreatment intra-canal samples using paper points and round burs were taken to assess phage and bacterial counts. Results: Part 1: We identified two phages (JBD4 and JBD44a) with putative biofilm degrading activities. Treatment of PA14 biofilms with these phages produced a significant reduction in the mean percentage of biomass in $24 \mathrm{~h}$ $(p<0.05)$ and 96h $(p=0.08)$ biofilms. Part 2: In 24 and 96h PA14 biofilms in a root canal model, no significant difference was found in the number of colony forming units after phage treatment $(p>0.05)$. Conclusion: Phage application significantly reduced the biomass of 24 and 96h PA14 biofilms grown on microplates, but did not produce significant reduction of 24 or $96 \mathrm{~h}$ PA14 biofilms grown in the extracted tooth model.
\end{abstract}




\section{Acknowledgments}

I would like to thank the members of my advisory committee, Dr. Bettina Basrani, Dr. Anil Kishen, and Dr. Alan Davidson. I would like to extend this thank you to include Dr. Karen Maxwell, who provided me with many hours of her time, a place to conduct my study, an endless amount of supplies, and laboratory instruction. This project would not have taken place without Dr. Maxwell's guidance. Dr. Amir Azarpazhooh provided statistical assistance and I am truly thankful for all of the time he devoted to this project. The writing and editing of this manuscript was completed with the help of Dr. Calvin Torneck, a big thank you is indeed indicated for all of his time.

The technical help from Diane Bona, Senjuti Saha, Mostafa Fatehi Hassanabad, Nichole Cumby, and Joe Bondy-Denomy was greatly appreciated. Without the lessons from Diane on how to perform the necessary laboratory techniques to complete the project and the understanding of the science behind these techniques from Joe I would not have been able to complete this project. Thank you to these members of the Maxwell and Davidson laboratories for all of their time and efforts.

Last but not least, I would like to thank Dr. Brian Phee, husband extraordinaire. From helping me come up with the initial idea of the project to picking me up in the middle of the night from the lab, he has gone out of his way to be supportive.

This study was supported in part by grants from the Canadian Academy of Endodontics Endowment Fund, the American Association of Endodontists Foundation, and an Operating Grant from the Canadian Institutes for Health Research to K.L.M. (Fund No. MOP-6279).

Aly Phee, June 2012 


\section{Table of Contents}

$\begin{array}{lll}\text { Abstract } & \text { ii }\end{array}$

$\begin{array}{ll}\text { Acknowledgements } & \text { iii }\end{array}$

Table of Contents $\quad$ iv

1. Introduction 1

$\begin{array}{lll}1.1 & \text { Primary Apical Periodontitis } & 1\end{array}$

1.2 Persistent Apical Periodontitis 2

$\begin{array}{lll}1.3 & \text { Biofilm } & 3\end{array}$

1.4 Biofilm in Endodontics 4

$\begin{array}{llr}1.5 & \text { Pseudomonas aeruginosa } & 6\end{array}$

1.6 Pseudomonas aeruginosa in Endodontics 7

$\begin{array}{lll}1.7 & \text { Bacteriophage Therapy } & 8\end{array}$

$\begin{array}{lll}1.8 & \text { Bacteriophage Therapy in Dentistry } & 10\end{array}$

\section{2: Objectives and Hypothesis}

$\begin{array}{lll}2.1 & \text { Objectives } & 11\end{array}$

$\begin{array}{ll}\text { 2.1.1 General Objectives } & 11\end{array}$

2.1.2 Specific Aims 11

$\begin{array}{lll}2.2 \text { Hypothesis } & 12\end{array}$

3: Article 13

4: Discussion 31 
5: Conclusions

6: References 


\section{Introduction}

Bacteriophages (phages) are obligate parasitic viruses that adsorb to bacterial cell surfaces via their tail by binding to a membrane bound phage receptor (1). While this binding is at times strain specific, most phages have a broader spectrum and retain an ability to infect several strains within a species $(2,3)$. Once bound to the bacterial cell receptor, phage DNA is injected into the host cell and can alter the bacterial DNA to disrupt its metabolism or cause its death $(3,4)$. This ability makes phages potentially useful in the reduction of viable bacteria. This study was undertaken to investigate the potential use of phages in the management of endodontic infections, primarily persistent root canal infections dominated by the presence of Pseudomonas aeruginosa.

\subsection{Primary Apical Periodontitis}

Primary apical periodontitis is an inflammatory response of the periodontal ligament and surrounding bone to infection present in the root canal system $(5,6)$. Bacteria and bacterial products in the root canal initially interact with resident and migrant host cells to initiate inflammation and destruction of the tissue present at anatomical sites along the dental root where blood vessels and nerves normally enter and exit the pulp space. The process then extends into the surrounding cancellous bone (7). While bacteria, can and often do, extend from the root canal into the inflamed tissue at these sites, the inflammation is mostly sustained by presence of bacteria in the root canal supported by an environment that is favorable to their growth. Successful treatment of root canal 
infection requires physical reduction in the number of root canal bacteria and an alteration in the root canal environment to one that does not encourage bacterial colonization and survival $(8,9)$. After treatment, an effective coronal seal to prevent the future ingress of bacteria must protect the new environment (10-13). Outcome studies that assess the efficacy of current treatment methods used in the management of root canal infections report a favorable response rate of $74-86 \%(14-17)$.

\subsection{Persistent Apical Periodontitis}

Persistent endodontic disease occurs when endopathic bacteria are not adequately controlled by the endodontic treatment or when new bacteria or other factors that promote disease are introduced into the root canal and periapical tissues during or after therapy. Unlike primary apical periodontitis, persistent disease can be caused not by just microorganisms, but also by cyst development in the inflamed apical tissue, and by the inadvertent introduction of foreign materials into the apical tissues during initial treatment (18-20). Microorganisms responsible for persistent disease can be those responsible for primary apical periodontitis that have survived the initial disinfection protocol and have adapted to the post treatment environment created in the root canal (primary persistence) (21), or new microorganisms that have gained access to, and colonized the root canal after initial treatment has been completed (secondary persistence) $(11,12,20,22-25)$. Predisposing factors that lead to primary persistence include inadequate aseptic control, missed anatomy, inadequate instrumentation, and inadequate debridement (26-29). Those factors that lead to secondary persistence and 
biofilm resilience include poor or broken coronal restorations, active caries, cracks, or poorly filled root canals $(10-13,18,30,31)$.

The microbiota associated with persistent disease is markedly different from that of primary disease $(32,33)$. Non-vital teeth with apical periodontitis and clinically intact crowns display a microbiota dominated (>90\%) by obligate anaerobes (34-37). Root canals exposed to saliva display a modest decrease in anaerobic bacteria (>70\%) and an increase in those that are facultative anaerobes (38). Unlike primary AP, the microbiota associated with persistent apical periodontitis is dominated by facultative microorganisms, particularly Gram-positive rods and cocci $(29,33)$. As a group these microorganisms display more resistance than those that are strictly anaerobic $(33,34,39$ 57). Both primary and persistent infections can be a mono-infection caused by a variety of species that include Pseudomonas, Actinomyces, or Enterococci (58-65). Like teeth with primary root canal infections, teeth with persistent infections also can be treated by non-surgical and/or surgical methods with an expected healing rate of $77-80 \%(66,67)$ and $74-76 \%(68,69)$ respectively.

\subsection{Biofilm}

Biofilm is a surface-associated complex bacterial community encased in a hydrated extracellular matrix of exopolysaccharides (EPS), proteins, nucleic acid, and lipids (70). They are generally heterogeneous, structurally organized microbial communities loosely connected by water channels and voids (71). The EPS component of the biofilm accounts for $50-90 \%$ of its organic carbon content and is highly hydrated due to their ability to 
incorporate water into its structure by hydrogen bonding. The hydration of the EPS protects the biofilm against desiccation (72), and affords the bacteria present in the biofilm sufficient environmental protection to achieve densities approximately 1000 fold greater than what would be achievable if they existed in planktonic form (73).

Biofilm formation begins when bacteria penetrate the hydrodynamic boundary of a compatible surface through the interplay of van der Waal's forces of electrostatic attraction and repulsion (74). These forces are general, long range, weak, and reversible. Binding to a surface becomes irreversible when stereo-chemical coupling between bacterial adhesion molecules and complementary surface receptors, occurs. Bacteria that possess a flagellum are able to overcome surface electrostatic repulsion faster than those that do not, and bacteria that manifest certain types and large numbers of adhesion molecules can also bind to a surface more efficiently than those that do not (74). Once attachment has been established, bacteria can aggregate and co-aggregate to increase the density and complexity of the biofilm. Some biofilm-forming bacteria, such as $P$. aeruginosa, exhibit a cell-to-cell molecular signaling mechanism (quorum sensing) that influences their adhesion potential. When signaling molecules reach a critical concentration, there is an increase in their expression of virulence and an enhancement in biofilm formation (74).

\subsection{Biofilm in Endodontics}

Ricucci and Siqueira (75) studied the prevalence of biofilm in endodontic disease and concluded that their incidence was consistent with the criteria necessary to classify apical 
periodontitis as a "biofilm-induced disease". They reported that biofilm was present in the apical third of the root canal in $77 \%$ of teeth examined, $80 \%$ in those that had not been endodontically treated, and $74 \%$ in those with root fillings. They also reported a positive relationship between the presence of biofilm and the radiographic size of the lesion. Other studies have reported the presence of biofilm at more diverse sites in root canals (76), in root canal ramifications and isthmuses (77), and on the exterior root surface (75). Their presence in teeth with persistent disease raised the question as to their possible role as an etiological factor in disease persistence.

Because of the potential of biofilm to cause disease is high, methods of root canal disinfection are continually being explored and assessed. Promising results in the disruption of biofilm have been reported with the use of photodynamic therapy (PDT) (78-81) and ultrasonic assisted irrigation using a wire or small endodontic file to propagate an energy wave $(82,83)$. Root canal irrigants, new and old, also have been assessed in regards to their biofilm disrupting potential. Most of these assessments were in vitro that use constructed biofilm grown on the dentin obtained from extracted teeth $(84,85)$, nitro-cellulose membranes $(86,87)$, or membrane filter discs $(88,89)$. These and other studies confirmed what had long been suspected, that sodium hypochlorite was effective in reducing bacterial mass, but required prolonged exposure ( $>30 \mathrm{~min})$ when commonly used dilutions ( $1 \%$ and $2.5 \%)$ were used. They noted that reduction is mass dependant upon factors including biofilm species, type, volume, and concentration of the irrigant, and duration of exposure (8,90-94). 


\subsection{Pseudomonas aeruginosa}

Pseudomonas aeruginosa, a member of the Gamma Proteobacteria class of bacteria, is a motile, Gram negative, facultative, rod-shaped bacterium measuring 0.5 to $0.8 \mu \mathrm{m}$ by 1.5 to $3.0 \mu \mathrm{m}$ in size $(95,96)$. Its optimum temperature for growth is $37^{\circ} \mathrm{C}$, but retains a growth potential at temperatures as high as $42^{\circ} \mathrm{C}$. It is resistant to high concentrations of salts and dyes, weak antiseptics, and many commonly used antibiotics. P. aeruginosa strains produce two types of soluble pigments, a fluorescent pigment pyoverdin, and a blue pigment, pyocyanin. The latter plays a role in its iron metabolism and is produced in abundance in low-iron content media (97).

Cell-surface polysaccharides produced by $P$. aeruginosa serve as a barrier between the cell wall and the environment, mediate host-pathogen interactions, and form structural components of its biofilm. Lipopolysaccharide (LPS) plays a key structural role in the outer membrane integrity of $P$. aeruginosa and acts as an important mediator of hostpathogen interactions during disease (98). P. aeruginosa is primarily a nosocomial pathogen and has been described as an opportunistic human pathogen that exploits a disruption in host defense to initiate infection (99). It often infects immune-compromised patients, like those with cystic fibrosis, cancer, or AIDS (100) and produces endocarditis, respiratory infections, bacteremia, septicemia, central nervous system infections, ear and eye infections, bone and joint infections, urinary tract infections, gastrointestinal infections, and skin and soft tissue infections (101).

P. aeruginosa is classified as a dangerous pathogen because it is resistant to therapeutic 
doses of commonly used antibiotics. The resistance is attributed to the impermeability of its outer membrane to antibiotic penetration, its ability to form an exopolysaccharideprotected (EPS) biofilm (101), the presence of multidrug efflux pumps in the cytosol, and chromosomally encoded antibiotic resistance genes. In addition to these intrinsic resistance factors, $P$. aeruginosa can easily acquire resistance by mutation of its chromosomally encoded genes or through horizontal gene transfer of antibiotic resistance determinants from plasmids (98). Recent studies have shown that phenotypic resistance associated with biofilm formation and the emergence of small-colony variants also may be important factors in its development of resistance (98).

\subsection{Pseudomonas aeruginosa in Endodontics}

P. aeruginosa has been recovered from primary and persistent endodontic infections (6365,102-107). Several studies have identified $P$. aeruginosa as a component of the root canal microbiota of primary endodontic infections $(65,106,107)$. Fujii et al. found $P$. aeruginosa represented $6.8 \%$ of the bacterial isolates recovered from twenty teeth with persistent apical infections (102). More importantly they found that four of five teeth with a draining sinus contained $P$. aeruginosa, and that in two of the twenty samples, $P$. aeruginosa occurred as a mono-species infection. This finding, coupled with the proven ability of some species to form biofilm, has identified P. aeruginosa as a putative pathogen in persistent endodontic disease. Its persistence after conventional endodontic treatment $(63-65,102-105)$ indicates that it also may express resistance to commonly used

endodontic disinfection protocols. This concept was supported experimentally by 
Raphael et al. who reported that irrigation with $5.25 \%$ sodium hypochlorite could not routinely eliminate $P$. aeruginosa from the root canal (108), and by Leonardo et al. who reported that growth of $P$. aeruginosa was not inhibited by several of the commonly used root canal sealers (109). A 48h intra-canal dressing of calcium hydroxide (110) and photodynamic therapy (PDT) (111) have reportedly been shown to be only partially effective in eliminating its presence. While the PDT study also reported only partial reduction in $P$. aeruginosa density, it reported that its degree of resistance was 100-1000 times that of E. faecalis, a microorganism that has been reported in several studies (112114) of persistent endodontic disease (111).

\subsection{Bacteriophage (phage) Therapy}

Phage therapy is an alternative in the management of persistent bacterial infections. Phages are obligate parasitic viruses that infect and kill bacteria. Tailed phages are the most numerous group. They display a protein shell and have a head that contains nucleic acid for encoding information required to direct its reproduction within a host bacterium, and a tail that allows them to attach and interact with their host cell. They initially adsorb to the bacterial cell wall via their tail fibers. While some phages are highly virulent and cause death of the host cell once they infect it, others are less lethal and just incorporate their DNA into host cell DNA to alter its function (115), and many phages can do both. Advantages of phage therapy include continuous self-replication of the phage at the site of infection and a host-specificity that leaves other bacterial and body cells undisturbed (116). Some phages have depolymerases as tail or spike fibers and this enables them to 
reach the bacterial cell wall when an EPS coating is present (117). Through their interaction with host cells, phages may cause biofilm disruption, lysis, and degradation of the EPS (70). Phage therapy is potentially broad in its application and can be particularly important in the treatment of bacterial infections that display multidrug resistance (118). It is currently being used in the food industry for the prevention of poultry infection (119), in the bacterial reduction of fresh produce (120), human cancer therapy (121), wound healing therapy (122), allergy prevention therapy (123), and in the control of opportunistic bacterial infections present in immuno-compromised mice (124).

One phage has shown an ability to effectively diffuse through $P$. aeruginosa EPS matrix (115) and retain an infection potential in the deeper layers of the biofilm by permeating the water channels in the biofilm core (125). This property makes this phage a useful tool in the management of deep infections. Cornelissen et al. have suggested that some phages are useful because EPS acts as their primary receptor where they induce a time and dose dependant degradation of the biofilm. This effect is independent of the bacterial strain and biofilm age (70). Other phages are effective because they induce a bacterial synthesis of enzymes that degrade polymers that occlude their cell wall (126). Glonti et al. for example, showed that infection of certain $P$. aeruginosa strains by phage PT-6 induced secretion of a hydrolyzing enzyme that degraded host EPS (127). A new phage created by Lu and Collins (128) was engineered to not only induce the expression of a biofilmdegrading enzyme, but also to destroy the host cell. The anti-biofilm potential of this phage proved to be significantly greater than that of the non-enzyme producing phage used as the experimental control. The ability to engineer a phage with specific properties 
demonstrates the potential that phage therapy may have in biofilm management in the future (128).

Clinical trials in which phage therapy have been used are limited. Hawkins et al. (129) reported a veterinary clinical trial of phage treatment in the management of $P$. aeruginosa ear infections in the dog. They found that a topical phage mixture applied to the infected ear led to $P$. aeruginosa lysis and a resolution of the infection without apparent detrimental effects to the dog's health. In a randomized, double-blinded, placebocontrolled Phase I/II clinical trial, Wright et al. (130) showed efficacy and safety of phage treatment in the management of antibiotic resistant $P$. aeruginosa induced chronic otitis in 24 patients where all showed improvement subsequent to the therapy (130).

\subsection{Phage Therapy in Dentistry}

The use of phage therapy in dentistry is limited. Shultz suggested its use in oral surgery and exodontias as early as 1932 (131). The only support for this suggestion was the encouraging reports of its use in other medical fields at that time. More recently, Paisano et al. (132) demonstrated that phage therapy could be used to reduce E. faecalis biofilm grown on dentin in vitro. In 2009 Stevens et al. reported on the recovery of a lysogenic phage from an infected root canal (133). The significance of this finding was not discussed. 


\section{Objectives and Hypothesis}

Interest in phage therapy, in particular the role that it may play in the management of endodontic infections, is limited at this time. However, in view of the reported in vivo efficacy in the management of $P$. aeruginosa infective chronic otitis, it may be an interesting and reasonable avenue to pursue $(129,130)$. Phage therapy may be a beneficial alternative or adjunctive disinfection strategy for the elimination of apical periodontitis. To this end a two-part study was undertaken.

\subsection{Objectives}

\subsubsection{General Objectives}

This study was designed to use an in vitro microplate assay as well as extracted tooth models to test the efficacy of bacteriophage treatment against a constructed $P$. aeruginosa biofilm.

\subsubsection{Specific Aims}

-To establish microplate assay parameters by testing different phages, combinations of phages, and the phage concentrations to identify the most effective and reproducible method of reducing the biomass.

-To establish a reproducible extracted tooth model for growing biofilms and testing the efficacy of bacteriophage treatment against the bacterial biomass. 
-To quantify post-treatment phage concentrations in both parts of the study and compare these values to the pre-treatment loading concentration.

-To identify the potential benefits and limitations of using phage addition for the purpose of reducing biomass.

\subsection{Hypothesis}

It was predicted that $P$. aeruginosa biomass would be reduced by the addition of preselected phages in a microplate assay and in extracted tooth models. Phage therapy would reduce a younger $24 \mathrm{~h}$ biofilm more effectively than an older $96 \mathrm{~h}$ biofilm. Posttreatment phage concentrations would be higher than the initial loading concentrations. 


\title{
3. Article
}

\section{Submitted for Publication: May 18, 2012}

\section{Title Page}

\section{Efficacy of bacteriophage treatment on Pseudomonas aeruginosa biofilms}

Alysen Phee, B.Sc., D.M.D.*, Joe Bondy-Denomy, B.Sc.**, Anil Kishen B.D.S, M.D.S., Ph.D.*, Bettina Basrani, D.D.S., M.Sc., Ph.D.*, Amir Azarpazhooh, D.D.S., M.Sc., Ph.D.*, Karen Maxwell, B.Sc., M.Sc., Ph.D.**

* Discipline of Endodontics, Faculty of Dentistry

** Terrance Donnelly Center for Cellular and Biomolecular Research

University of Toronto, Toronto, Ontario Canada

Address requests for reprints to: Dr. A. Kishen

\author{
Endodontics, Faculty of Dentistry \\ University of Toronto \\ 124 Edward St., Toronto, Ontario M5G 1G6, Canada \\ E-mail address: anil.kishen@dentistry.utoronto.ca
}

Acknowledgement: The authors deny any conflicts of interest.

This study was supported by grants from the American Association of Endodontists Foundation and the Canadian Academy of Endodontics Endowment Fund. This work was supported in part by an Operating Grant from the Canadian Institutes for Health Research to K.L.M. (Fund No. MOP-6279). The authors thank Dr. Calvin Torneck for his editing and Diane Bona for her technical assistance. 


\begin{abstract}
Introduction: Bacterial viruses (phages) have been used successfully in the treatment of animal and human bacterial infections. This study examined the potential use of phage therapy against Pseudomonas aeruginosa strain PA14 biofilms in a root canal model. Methods: Part 1: 24 and 96h PA14 biofilms grown in microplates were treated with phages identified as possessing potential biofilm degrading activities and the posttreatment bacterial biomass was quantified using crystal violet staining. Part 2: 24 and 96h PA14 biofilms grown in prepared root canals of extracted human mandibular incisors were treated with phages identified with potential biofilm-degrading activities. Posttreatment intra-canal samples using paper points and round burs were taken to assess phage and bacterial counts. Results: Part 1: We identified two phages (JBD4 and JBD44a) with putative biofilm degrading activities. Treatment of PA14 biofilms with these phages produced a significant reduction in the mean percentage of biomass in $24 \mathrm{~h}$ $(p<0.05)$ and 96h $(p=0.08)$ biofilms. Part 2: In 24 and 96h PA14 biofilms in a root canal model, no significant difference was found in the number of colony forming units after phage treatment $(p>0.05)$. Conclusion: Phage application significantly reduced the biomass of 24 and 96h PA14 biofilms grown on microplates, but did not produce significant reduction of 24 or $96 \mathrm{~h}$ PA14 biofilms grown in the extracted tooth model.
\end{abstract}

Keywords: Pseudomonas aeruginosa, bacteriophage therapy, apical periodontitis, root canal

\title{
Introduction
}

Primary apical periodontitis is an inflammatory response of the periodontal ligament and surrounding bone to infection within the root canal system (1). Successful treatment of root canal infection requires physical reduction in the number of root canal bacteria and an alteration in the environment that discourages bacterial re-colonization and survival (2). Outcome studies that assess the efficacy of current treatment methods used in the management of root canal infections report a favorable healing rate of $68-85 \%$ (3). Persistent endodontic disease occurs when endopathic bacteria are not adequately controlled or when new microorganisms are introduced into the root canal and periapical 
tissues, during or after initial treatment (4). Teeth with persistent infections can be treated non-surgically and/or surgically and have an expected healing rate of $80 \%$ (5) and $74 \%$ (6) respectively. A study of the prevalence of endodontic biofilm reported its presence in the apical third of the root canal system in $80 \%$ of untreated teeth with AP and in $74 \%$ of those with root fillings (7). This is consistent with the criteria necessary to classify apical periodontitis as a "biofilm-induced disease".

A potential cause of endodontic infections is Pseudomonas aeruginosa, a Gram-negative, facultative, rod-shaped bacterium that belongs to the Gamma Proteobacteria class of bacteria (8). It has been recovered from primary and persistent endodontic infections (1017) and in one study represented $6.8 \%$ of the bacterial isolates recovered from persistent apical infections (10). Notably, in that study P. aeruginosa was found in four of five teeth with a draining sinus, two of which appeared to be a mono-species infection. $P$. aeruginosa is resistant to high concentrations of salts, dyes, weak antiseptics, and many commonly used antibiotics (9). Its persistence after conventional endodontic treatment (10-15) also indicates that it may be resistant to commonly used endodontic disinfection protocols. Irrigation with $5.25 \%$ sodium hypochlorite did not routinely eliminate $P$. aeruginosa from the root canal (18), and growth was not inhibited by frequently used root canal sealers (19). A 48h intra-canal dressing of calcium hydroxide (20) and photodynamic therapy (PDT) (21) have also been shown to be ineffective in eliminating its presence. These findings, coupled with the ability of $P$. aeruginosa to form biofilms, are sufficient to designate $P$. aeruginosa as a possible cause of persistent endodontic disease.

A potent anti-biofilm strategy that is passive to host tissue is necessary in endodontics to augment the limited mechanical bacterial debridement and antiseptic agents used. Bacteriophages (phages) are viruses that can infect and kill bacteria. They have been used as a treatment alternative in the management of non-dental persistent bacterial infections (22). Advantages of phage therapy include continuous self-replication of the phage at the site of infection and a host-specificity that leaves the other bacterial and human cells undisturbed (23). Through their interaction with bacteria, phages can degrade the extracellular matrix of exopolysaccharides (EPS), proteins, lipids, and nucleic acids that 
comprise the bacterial biofilm community, leading to disruption of the biofilm and subsequent lysis of the bacterial cells (24).

The clinical use of phage therapy has been explored in the management of $P$. aeruginosa ear infections in dogs (25). A topical phage mixture applied to the infected ear led to $P$. aeruginosa lysis and a resolution of the infection, without apparent detrimental effects to general health. In a 2009 randomized, double-blinded, placebo-controlled Phase I/II clinical trial the efficacy and safety of phage therapy was demonstrated for the management of antibiotic resistant $P$. aeruginosa induced chronic otitis in 24 human patients (26). Phage therapy studies are limited in dentistry. They have been shown to reduce Enterococcus faecalis biofilm grown on human dentin (27) and they have been recovered from lysogenic E. faecalis strains isolated from infected root canals (28). In view of its specific antibacterial potential, this study was undertaken to investigate the efficacy of phage therapy in reducing $P$. aeruginosa biofilms grown in microwell plates and extracted tooth models.

\section{Materials and Methods}

\section{Part 1: Characterization of biofilm-degrading phages and microwell plate assay}

\section{Phage isolation and propagation}

Eighty phages isolated from $P$. aeruginosa samples from both environmental and clinical sources were assessed for potential exopolysaccharide-degrading activity. Serial dilutions of the phages were titered on P. aeruginosa strain UCBPP-PA14 (PA14) and the plaques were examined for halo production, indicating the potential presence of polysaccharide depolymerases. Two halo producing phages, JBD4 and JBD44a, isolated from strains ATCC 15524 and Env110BP, respectively, were identified as having potential biofilmdegrading activity. High titer lysates of these phages were prepared by mixing plaque purified phage with PA14 and top-plating in $0.7 \%$ lysogeny broth (LB) agar supplemented with $10 \mathrm{mM} \mathrm{MgSO}_{4}$.

Phages were collected from the plates by soaking in suspension medium (SM; $100 \mathrm{mM}$ sodium chloride, $10 \mathrm{mM} \mathrm{MgSO}$, $50 \mathrm{mM}$ Tris- $\mathrm{HCl}, \mathrm{pH} 7.5,0.01 \%$ (w/v) gelatin), to 
which DNAse $(5 \mu \mathrm{g} / \mathrm{mL})$ and RNAse $(5 \mu \mathrm{g} / \mathrm{mL})$ was added (29). The phage lysates were passed through a $0.45 \mu \mathrm{m}$ filter and the phage particles were concentrated by precipitation using polyethylene glycol $8000\left(16 \mathrm{~h}\right.$ stirring at $\left.4^{\circ} \mathrm{C}\right)$ and centrifugation (11,000 rpm for 20 minutes). The phage pellets were re-suspended in SM and the phage were banded on two sequential cesium chloride-equilibrium gradients $(50,000 \mathrm{rpm}, 24 \mathrm{~h})$. The phage bands were extracted and dialyzed into SM before further characterization.

\section{Biofilm treatment assay}

PA14 biofilms were grown using a modified version of the Calgary Biofilm Device that was previously shown to grow reproducible $P$. aeruginosa biofilms (30). A saturated overnight culture of PA14 in $0.5 \mathrm{X}$ LB broth was adjusted to an optical density of 0.4 at $600 \mathrm{~nm}\left(\sim 6 \times 10^{8}\right.$ colony-forming units $(\mathrm{CFU} / \mathrm{mL})$ and used for inoculation. $150 \mu \mathrm{L}$ of $0.5 \mathrm{X}$ LB was placed in 95 wells of two 96-well flat bottom microtiter plates and 84 wells were seeded with $5 \mu \mathrm{L}$ of the PA14 inoculum (NUNC; Rochester, NY). A transferable solid-phase (TSP) pin lid (NUNC; Rochester, NY) was placed into the microtiter plate and incubated with shaking at $37^{\circ} \mathrm{C}$ for 24 or $96 \mathrm{~h}$ to allow biofilm growth. The TSP pin lid was then removed, rinsed in sterile water, air dried for 30 seconds, and transferred to a 96-well plate in which the wells contained JBD4, JBD44a, or a combination of the two at a final concentration of $\sim 6 \times 10^{6} \mathrm{pfu} /$ well in $0.5 \mathrm{X}$ LB. The plate was incubated overnight at $37^{\circ} \mathrm{C}$.

The phages present in the wells following the overnight incubation with the biofilms were enumerated using the double agar overlay method (31). $125 \mu \mathrm{L}$ of solution was removed from wells containing JBD4, JBD44a, or the combination, and was sterilized by the addition of 5 drops of chloroform. The samples were centrifuged at 10,000 rpm for 5 minutes to remove bacterial cell debris. Serial dilutions of the supernatant were plated to determine the number of plaque forming units (PFU) present in each well.

\section{Quantification of biofilm remaining after phage treatment}

Following incubation with the phages, the TSP pin lid was rinsed with sterile water to remove unattached cells and air dried for 5 minutes. The pins were then immersed in a 
$1 \%$ crystal violet solution for 1 minute followed by three 30 -second rinses in sterile water. The crystal violet remaining adsorbed to the cell mass on the pins of the lid was solubilized by soaking the TSP pin lid in a 96-well plate containing $70 \%$ ethanol (1 hour, $25^{\circ} \mathrm{C}$ ) and the absorbance was determined for each well. The solubilized crystal violet was used as a measurement of biomass remaining on the pins (30).

\section{Part 2: In vitro biofilm assay in the root canal model}

\section{Specimen preparation}

The Research Ethics Board of the University of Toronto approved the collection and use of extracted human teeth for experiments conducted in this study. Twenty-eight intact, non-carious, human mandibular incisors without visible evidence of cracks, maintained in phosphate buffered solution, were used in this study. Teeth were radiographed to confirm the presence of a single canal and then decoronated to create a standardized root length of $15 \mathrm{~mm}$. Access into the pulp chambers was made with a high-speed bur under water coolant, and the working length was established with a $10 \mathrm{~K}$-type file $1 \mathrm{~mm}$ short of the apical exit. The root canals were prepared with ProTaper (Dentsply Tulsa Dental Specialties; Tulsa, OK) rotary instruments to size F5 with copious $(10 \mathrm{~mL})$ intermittent irrigation of $2.5 \%$ sodium hypochlorite. A longitudinal groove of $0.5 \mathrm{~mm}$ was prepared on the facial and lingual surfaces of the roots with a diamond disc (Brasseler USA; Savannah, GA) and the apex sealed with two coats of varnish. Specimens were then autoclaved in distilled water at $121^{\circ} \mathrm{C}$ for 20 minutes. They were dried with sterile cotton gauze and paper points immediately prior to use.

\section{Biofilm treatment assay}

The teeth were randomly assigned to 24 and $96 \mathrm{~h}$ biofilm periods $(n=14)$. One tooth in each group received $5 \mu \mathrm{L}$ of $0.5 \mathrm{X} \mathrm{LB}$ (control), while the rest of the teeth were inoculated with $5 \mu \mathrm{L}$ PA14 $\left(\sim 5 \times 10^{7} \mathrm{CFU} / \mathrm{mL}\right)$. This concentration is comparable to that used in previously reported phage therapy trial of human dentin infected with E. faecalis $\left(2 \times 10^{8}\right.$ $\mathrm{CFU} / \mathrm{mL}$ ) (27). Each tooth was placed vertically in a well of a 96-well plate, covered with parafilm and incubated at $37^{\circ} \mathrm{C}$ in a shaking incubator. After $24 \mathrm{~h}$, three groups of 3 
teeth each were treated with phages at a final concentration of $\sim 10^{7} \mathrm{PFU} /$ tooth: (a) $5 \mu \mathrm{L}$ JBD4; (b) $5 \mu \mathrm{L} \mathrm{JBD44a;} \mathrm{(c)} 2.5 \mu \mathrm{L}$ of each JBD4 and JBD44a. Four teeth remained untreated with phage. The treatment microwell plate was incubated at $37^{\circ} \mathrm{C}$ and media replenishment was provided for the $96 \mathrm{~h}$ growth at $48 \mathrm{~h}$. At the end of the incubation period a coarse paper point (Dentsply Tulsa Dental Specialties; Tulsa, OK) was used to extract the contents of each canal and transfer it to a sterile Eppendorf tube containing 1 $\mathrm{mL} 0.5 \mathrm{X}$ LB. In addition, a size 2 round bur was used to remove dentin shavings in the coronal third of the tooth ( 3 seconds at 3,200 rpm) and the bur was transferred to a sterile Eppendorf tube containing $1 \mathrm{~mL} 0.5 \mathrm{X}$ LB. The tubes were incubated at $48^{\circ} \mathrm{C}$ for $1 \mathrm{~h}$ before being vortexed, diluted, spread plated on LB and incubated at $37^{\circ} \mathrm{C}$ for $16 \mathrm{~h}$ to determine the CFUs. Post-treatment phage concentrations were determined by removing $100 \mu \mathrm{L}$ from the paper point and bur samples, sterilizing with chloroform, and plating serial dilutions. All experiments were performed in triplicate.

\section{Scanning Electron Microscopy}

To visually inspect the bacterial presence along the root canal, two random specimens from the positive control group were prepared for scanning electron microscopy (Amray 1830; San Jose, CA). The specimens were fixated by placement in $2.5 \%$ gluteraldehyde in $0.1 \mathrm{M}$ phosphate buffered solution for $24 \mathrm{~h}$. The specimens were then sectioned longitudinally with a razor blade and serially dehydrated in dilutions of ethanol. The specimens were mounted and sputter-coated with gold/palladium alloy before examination.

\section{Statistical Analysis}

Descriptive data and statistical analyses were performed utilizing the SPSS 17.0 software package (SPPS Inc. Chicago IL). One-way analysis of variance (ANOVA) with least significance difference (Fisher's LSD) post-hoc comparisons was conducted to compare the bacteriophage treatment of the samples within each group. Independent $t$-tests were also conducted on each group at the two different growth time intervals. All statistical analyses were interpreted at a 5\% level of significance. 


\section{Results}

\section{Part 1: Characterization of the biofilm degrading activity of JBD4 and JBD44a}

Analysis of the plaque morphology of 80 temperate phages isolated from induced $P$. aeruginosa strains led to the identification of two phages (JBD4 and JBD44a) that formed turbid plaques with halos, suggesting the presence of EPS-degrading activity. JBD4 and JBD44a were propagated twice on PA14 and banded on a cesium chloride gradient to ensure a pure phage stock. We examined these phages using negative stain transmission electron microscopy and discovered that both were members of the Siphoviridae family of phages (Fig. 1A). This class of phages possesses an icosahedral head containing a double stranded DNA genome attached to a long, non-contractile tail through which it interacts with the bacterial host cell.

The ability of phages JBD4 and JBD44a, alone and in combination, to degrade PA14 biofilms was characterized in 96-well microplates. $24 \mathrm{~h}$ and $96 \mathrm{~h}$ time points were chosen as previous studies revealed that $24 \mathrm{~h} P$. aeruginosa biofilms were susceptible to selected antibiotics, and that increased antibiotic resistance occurred in biofilms grown for greater than $48 \mathrm{~h}$ (32-35). As expected, the untreated 96h samples contained significantly more biomass $(p<0.001)$ than the $24 \mathrm{~h}$ biofilms. The addition of phages JBD4 and JBD44a into wells containing pre-formed biofilms produced a significant reduction in the mean percentage of bacterial biomass in $24 \mathrm{~h}(p<0.05)$ and $96 \mathrm{~h}(p<0.003)$ samples (Fig. 2). There was no additional decrease in the bacterial biomass with treatment using the phages in combination as compared to using them individually in either time period $(p=0.08)$.

To assess whether the phages were actively replicating during the course of the assay, phage titers were determined for a number of individual treatment wells following the $24 \mathrm{~h}$ incubation period. As shown in Table 1, the titers of both JBD4 and JBD44a increased approximately 10-fold, indicating that the phages are infecting the cells, replicating within them, and being released back into the medium following cell lysis. There was no significant difference in the number of phages released when using JBD4 and JBD44a alone or in combination in the $24 \mathrm{~h}$ or $96 \mathrm{~h}$ biofilms. 


\section{Part 2: Phage biofilm degrading activity in the root canal model}

After confirming that phages JBD4 and JBD44a can infect and kill PA14 cells growing as a biofilm in the microplate assay, their ability to eradicate PA14 biofilm in the more biologically relevant tooth model was assessed. The growth of biofilm on the tooth surface was examined in a $24 \mathrm{~h}$ biofilm using scanning electron microscopy, which confirmed the presence of a layer of bacterial cells adhered to the dentin surface (Fig. 1B).

Analysis of both planktonic and biofilm-forming cells in the untreated samples in the root canal model revealed an increase in the number of CFUs in the 96h sample as compared to the $24 \mathrm{~h}$ time point (Table 2). The $96 \mathrm{~h}$ biofilm was determined to have a 5 -fold increase in the number of cells adhered to the surface of the teeth as compared with the $24 \mathrm{~h}$ biofilm. This is consistent with the findings of increased biomass in the $96 \mathrm{~h}$ biofilms in the microplate assay. The addition of phages JBD4, JBD44a, or a combination of the two did not significantly decrease the number of planktonic or biofilm-adhered cells in the 24 h or 96 h samples (Table 2 ).

While there was no appreciable difference in cell counts following treatment with the phages, the number of phages present at the end of the incubation period was analyzed to assess their replication. Since JBD4 and JBD44a were isolated from bacterial cells in which they were maintained as lysogens, and they produce turbid plaques on PA14 suggesting the formation of lysogens, it is likely that they also formed lysogens in this assay. This would provide resistance to further phage infection to cells in which the phage lysogen had integrated and could confound the resistant bacterial cell count numbers. The number of phages present in the planktonic fraction of the root canal increased by 100 - to 1000 -fold over the course of the experiment (Table 3). This illustrates that the phages were actively infecting, replicating within, and lysing the bacterial population even though the bacterial counts did not decrease over the time course of the experiment. Further, the bur assay shows that while the $24 \mathrm{~h}$ biofilm samples contained phages at approximately the same concentration as they were seeded into the assay, the $96 \mathrm{~h}$ biofilms averaged 100- to 1000-fold more phages associated with them. 
This is especially interesting to note as the number of bacterial cells in the $96 \mathrm{~h}$ biofilm was only increased 5-fold above the $24 \mathrm{~h}$ biofilm.

\section{Discussion}

Unlike endodontic management of primary infections, the treatment of persistent infection often can be more specific and directed towards the elimination of a lesser number of identifiable species (4). One species identified as a cause of persistent disease in endodontics is $P$. aeruginosa (10-15), a Gram-negative opportunistic pathogen capable of forming biofilms that are resistant to antibiotics. Pseudomonas phage therapy has been successfully used for the management of persistent antibiotic-resistant otitis infections in humans and dogs $(25,26)$, as well as for the treatment of E. faecalis biofilms grown on dentin (27). For these reasons, we investigated the use of phage therapy for the treatment of $P$. aeruginosa infections in root canal models.

The phages used in this study, JBD4 and JBD44a, were initially selected for their ability to produce plaques with halos, which is suggestive of the ability to degrade exopolysaccharides, a component of the extracellular matrix present in biofilms. We assessed the efficacy of a combination of the two phages in addition to their individual use as previous clinical trials reported the success of phage mixtures in the management of human and animal $P$. aeruginosa otitis infections $(25,26)$. In a microwell plate assay, bacteriophage treatment significantly reduced the biomass of 24h and 96h PA14 biofilms in the microplate assay, but complete bacterial elimination was not observed. In contrast, there was no significant reduction of viable bacterial counts of 24h or 96h PA14 biofilms in the extracted tooth model. Two sampling methods were used in the extracted tooth model. Paper point absorption was specifically chosen to recover planktonic bacteria and phages present within the root canal lumen $(12-16,27)$ and round burs were used to recover bacteria and phages adherent to the root canal wall, as well as those that might be present in the root dentin. Disparity in biomass reduction between the microwell plate assay and the extracted tooth model may possibly be attributed to the inability of the phages to effectively reach all parts of the root canal anatomy and penetrate dentinal tubules. 
While both JBD4 and JBD44a were able to decrease the biomass in the microwell plate assay, complete elimination of bacteria was never observed, and the combination of phages did not demonstrate a significant reduction as compared to the individual phages with the same final concentration. It was suspected that lysogens of these phages might provide resistance to further phage infection to their bacterial hosts, and characterization of lysogens of JBD4 and JBD44a in PA14 indicated this to be correct (data not shown). Thus, PA14 into which either phage inserts as a lysogen are resistant to both JBD4 and JBD44a. Whether this resistance is provided by immunity due to the phage repressor or another mechanism is unknown. If it is repressor-mediated immunity, it can be overcome by engineering a virulent mutant of the phage that lacks the ability to form lysogens. The ability of JBD4 and JBD44a to form lysogens confounds the results of this study as the cells that persist in the assays are expected to be a mixture of bacterial cells that have integrated either JBD4 or JBD44a as a lysogen, and bacterial mutants that are able to interfere with the phage life cycle, thereby preventing it from infecting or replicating. Additional studies using virulent mutants of these phages will be required to fully deconvolute these results.

Previous phage therapy studies that examined the post-treatment phage concentrations found them to be significantly higher than the initial concentrations $(25,26,34)$. In this study the phages were also able to replicate, and the final titers from the extracted tooth model were 100- to 1000-fold higher than were input into the assay. The propagation of phages in the assay illustrated their ability to infect cells, replicate within them, and lyse them, even though there was no corresponding decrease in bacterial cell counts. The lack of decrease in biomass adhered to the dentin of the teeth, as evidenced by the cell counts from the bur samples, suggested that the phages might have difficulty effectively penetrating the $P$. aeruginosa biofilms formed within a root canal. This could result from difficulty in delivering effective phage concentration to the infected site. Improved phage administration and encouraging their diffusion through the root canal system will be required for them to be effective in this environment.

While phage therapy has been effective in the management of some infections, further research into the most effective phage or phages combination is required before it is 
practical for the treatment of endodontic infections. The use of virulent phages that are unable to form lysogens is a necessary step, and engineering of such phages will be undertaken. 


\section{References}

1. Möller AJ, Fabricius L, Dahlén G, Ohman AE, Heyden G. Influence on periapical tissues of indigenous oral bacteria and necrotic pulp tissue in monkeys. Scan J Dent Res 1981;89:475-84.

2. Byström A, Sundqvist G. The antibacterial action of sodium hypochlorite and EDTA in 60 cases of endodontic therapy. Int Endod J 1985;18:35-40.

3. Ng YL, Mann V, Rahbaran S, Lewsey J, Gulabivala K. Outcome of primary root canal treatment: systematic review of the literature-Part 1. Effects of study characteristics on probability of success. Int Endod J 2007;40:921-39.

4. Nair PN, Sjögren U, Krey G, Kahnberg KE, Sundqvist G. Intraradicular bacteria and fungi in root-filled, asymptomatic human teeth with therapy-resistant periapical lesions: a long-term light and electron microscopic follow-up study. J Endod 1990;16:580-8.

5. Ng YL, Mann V, Gulabivala K. A prospective study of the factors affecting outcomes of non-surgical root canal treatment: part 1: periapical health. Int Endod J 2011;44:583-609.

6. Barone C, Dao TT, Basrani BB, Wang N, Friedman S. Treatment outcomes in endodontics: The Toronto study-Phases 3,4, and 5: Apical surgery. J Endod 2010;36:28-35.

7. Ricucci D, Siqueira JF. Biofilms and apical periodontitis: study of prevalence and association with clinical and histological findings. J Endod 2010;36:1277-88.

8. Anzai et al. Phylogenetic affiliation of the pseudomonads based on $16 \mathrm{~S}$ rRNA sequence. Int J Syst Evol Microbiol 2000;50:1563-89.

9. King EO, Ward MK, Raney DE. Two simple media for the demonstration of pyocyanin and fluorescein. J Lab Clin Med 1954;44:301-7.

10. Fujii R, Saito Y, Tokura Y, Nakagawa KI, Okuda K, Ishihara K. Characterization of bacteria flora in persistent apical periodontitis lesions. Oral Microbiol Immunol 2009;24:502-5.

11. Siqueira JF, Rôças IN. Clinical implications and microbiology of bacterial persistence after treatment procedures. J Endod. 2008;34:1291-1301.

12. Cheung GSP, Ho MWM. Microbial flora of root canal-treated teeth associated with asymptomatic periapical radiolucent lesions. Oral Microbiol Immunol 2001;16:332-7. 
13. Molander A, Reit C, Dahlén G, Kvist T. Microbiological status of root-filled teeth with apical periodontitis. Inter Endod J 1998;31:1-7.

14. Tronstad L, Barnett F, Riso K, Slots J. Extraradicular endodontic infections. Dent Traumatol 1987;3:86-90.

15. Ranta K, Haapasalo M, Ranta H. Monoinfection of root canal with Pseudomonas aeruginosa. Endod Dent Traumatol 1988;4:269-72.

16. Siren EK, Haapasalo MPP, Ranta K, Salmi P. Microbiological findings and clinical treatment procedures in endodontic cases selected for microbiological investigation. Int Endod J. 1997;30:91-5.

17. Tsatsas B, Tzamouranis A, Mitsis F. An examination of root canals before filling. Inter Endod J 1974;7:78-80.

18. Raphael D, Wong TA, Moodnik R, Borden BG. The effect of temperature on the bactericidal efficiency of sodium hypochlorite. J Endod 1981;7:330-4.

19. Leonardo MR, da Silva LAB, Filho MT, Bonifacio KC, Ito IY. In vitro evaluation of antimicrobial activity of sealers and pastes used in endodontics. J Endod 200;26:391-4.

20. Estrela C, Pimenta FC, Ito IY, Bammann LL. In vitro determination of direct antimicrobial effect of calcium hydroxide. J Endod 1998;24:15-7.

21. Garcez AS, Ribeiro MS, Tegos GP, Nunez SC, Jorge AOC, Hamblin MR. Antimicrobial photodynamic therapy combined with conventional endodontic treatment to eliminate root canal biofilm infection. Lasers in Surgery 2007;39:5966.

22. Donlan R. Preventing biofilms of clinically relevant organisms using bacteriophage. Trend Microbiol 2009;17:66-72.

23. Clark JR, March JB. Bacteriophages and biotechnology: vaccines, gene therapy and antimicrobials. Trends Biotechnol 2006;24:212-8.

24. Cornelissen A, Ceyssens PJ, T'Sen J, Praet HV, Noben JP, Shaburova OV, et al. The T7-Related Pseudomonas putida Q15 Displays Virion-Associated Biofilm Degradation Properties. Plos One 2011;6:e18597.

25. Hawkins C, Harper D, Burch D, Änggård E, Soothill J. Topical treatment of Pseudomonas aeruginosa otitis of dogs with a bacteriophage mixture: A before/after clinical trial. Veter Micro 2010;146:309-13.

26. Wright, A, Hawkins, CH, Änggård E, Harper, DR. A controlled clinical trial of a 
therapeutic bacteriophage preparation in chronic otitis due to antibiotic-resistant Pseudomonas aeruginosa; a preliminary report of efficacy. Clin Otolaryngol 2009;34,:349-57.

27. Paisano AF, Spira B, Cai S, Bombana AC. In vitro antimicrobial effect of bacteriophages on human infected dentin with Enterococcus faecalis ATCC 29212. Oral Microbiol Immunol 2004;19:327-30.

28. Stevens RH, Porras OD, Delisle AL. Bacteriophages induced from lysogenic root canal isolates of Enterococcus faecalis. Oral Microbiol Immunol 2009;24:278-84.

29. Maniatis T, Ptashne M. Multiple repressor binding at the operators in bacteriophage lambda. Proc Nat Acad Sci USA 1973;70:1531-5.

30. Ceri H, Olsen ME, Stremick C, Read RR, Morck D, Buret A. The Calgary biofilm device: New technology for rapid determination of antibiotic susceptibilities of bacterial biofilms. J Clin Microbiol 1999;37:1771-6.

31. Mazzocco A, Waddell TE, Lingohr E, Johnson RP. Enumeration of bacteriophages by the direct plating plaque assay. Methods Mol Biol 2009;501:77-80.

32. Wolcott RD, Rumbaugh KP, James G, Schultz G, Philips P, Yang Q, Watters C, Stewart PS, Dowd SE. Biofilm maturity studies indicate sharp debridement opens a time-dependant therapeutic window. J Wound Care 2010;19:320-8.

33. O'Toole GA, Pratt LA, Watnick PI, Newman DK, Weaver VB, Kolter R. Genetic approaches to study biofilms. Methods Enzymol 1999;310:91-109.

34. Pires D, Sillankorva S, Faustino A, Azeredo J. Use of newly isolated phages for control of Pseudomonas aeruginosa PA01 and ATCC 10145 biofilms. Res Microbiol 2011;162:798-806.

35. Knezevic P, Petrovic O. A colorimetric plate method for assessment of phage effect on Pseudomonas aeruginosa biofilm. J Microbiol Methods 2008;74:114-8. 


\section{Figure Legends}

Figure 1. A. Negative stain transmission electron microscopy image of phages JBD4 and JBD44a. B. Scanning electron microscopy image of $P$. aeruginosa on the dentin surface of an inoculated root canal specimen.

Figure 2: Mean percentage of biomass removal as detected by a crystal violet assay for 24 and 96 hours of PA14 growth with untreated PA14 as $100 \%$. * Significance $p<0.05$ for all except 24h JBD4/JBD44a. 
Table 1. Post-treatment phage concentrations in 24 and 96h PA14 biofilms grown on microwell plates. No significance was detected.

\begin{tabular}{cccc}
\cline { 2 - 4 } & $\begin{array}{c}\text { Initial Phage Titer } \\
(\mathrm{PFU} / \mathrm{mL})\end{array}$ & $\begin{array}{c}24 \mathrm{~h} \mathrm{Biofilm} \\
\text { Titer }(\mathrm{PFU} / \mathrm{mL})\end{array}$ & $\begin{array}{c}96 \mathrm{~h} \text { Biofilm } \\
\text { Titer }(\mathrm{PFU} / \mathrm{mL})\end{array}$ \\
\hline JBD4 & $7.6 \times 10^{7}$ & $3.1 \times 10^{8}$ & $2.1 \times 10^{8}$ \\
JBD44a & $6.4 \times 10^{7}$ & $2.2 \times 10^{8}$ & $1.9 \times 10^{9}$ \\
JBD4/JBD44a & $7.0 \times 10^{7}$ & $4.0 \times 10^{8}$ & $7.0 \times 10^{8}$ \\
\hline
\end{tabular}

Table 2. The viable bacterial counts after $24 \mathrm{~h}$ and $96 \mathrm{~h}$ of growth in extracted teeth models. No significance was detected..

\begin{tabular}{ccccc}
\cline { 2 - 5 } & \multicolumn{2}{c}{ Paper Point Assay } & \multicolumn{2}{c}{ Bur Assay } \\
\cline { 2 - 5 } & $\begin{array}{c}\text { 24h Bacterial } \\
\text { Count }(\mathrm{CFU} / \mathrm{mL})\end{array}$ & $\begin{array}{c}\text { 96h Bacterial } \\
\text { Count }(\mathrm{CFU} / \mathrm{mL})\end{array}$ & $\begin{array}{c}\text { 24h Bacterial } \\
\text { Count }(\mathrm{CFU} / \mathrm{mL})\end{array}$ & $\begin{array}{c}\text { 96h Bacterial } \\
\text { Count }(\mathrm{CFU} / \mathrm{mL})\end{array}$ \\
\hline PA14 untreated & $4.8 \times 10^{7}$ & $9.6 \times 10^{8}$ & $1.5 \times 10^{6}$ & $5.2 \times 10^{6}$ \\
JBD4 & $1.7 \times 10^{8}$ & $6.8 \times 10^{8}$ & $1.3 \times 10^{6}$ & $1.2 \times 10^{7}$ \\
JBD44a & $4.8 \times 10^{7}$ & $9.8 \times 10^{8}$ & $1.2 \times 10^{6}$ & $8.8 \times 10^{6}$ \\
JBD4/JBD44a & $1.6 \times 10^{8}$ & $7.0 \times 10^{8}$ & $4.0 \times 10^{6}$ & $1.6 \times 10^{6}$ \\
\hline
\end{tabular}

Table 3. The post-treatment phage concentrations in $24 \mathrm{~h}$ and $96 \mathrm{~h}$ PA14 biofilms grown in extracted teeth models. No significance was detected.

\begin{tabular}{cccccc}
\cline { 3 - 5 } & & \multicolumn{2}{c}{ Paper Point Assay } & \multicolumn{2}{c}{ Bur Assay } \\
\cline { 3 - 6 } & $\begin{array}{c}\text { Initial } \\
\text { Titer }\end{array}$ & $\begin{array}{c}24 \mathrm{~h} \text { Titer } \\
(\mathrm{PFU} / \mathrm{mL})\end{array}$ & $\begin{array}{c}96 \mathrm{~h} \text { Titer } \\
(\mathrm{PFU} / \mathrm{mL})\end{array}$ & $\begin{array}{c}24 \mathrm{~h} \text { Titer } \\
(\mathrm{PFU} / \mathrm{mL})\end{array}$ & $\begin{array}{c}96 \mathrm{~h} \text { Titer } \\
(\mathrm{PFU} / \mathrm{mL})\end{array}$ \\
\hline JBD4 & & & & \\
\hline JBD44a & $2.6 \times 10^{7}$ & $1.8 \times 10^{10}$ & $2.4 \times 10^{10}$ & $9.4 \times 10^{7}$ & $9.5 \times 10^{10}$ \\
JBD4/JBD44a & $2.4 \times 10^{7}$ & $3.2 \times 10^{9}$ & $4.3 \times 10^{9}$ & $7.0 \times 10^{7}$ & $1.0 \times 10^{10}$ \\
\hline
\end{tabular}


Figure 1. A.

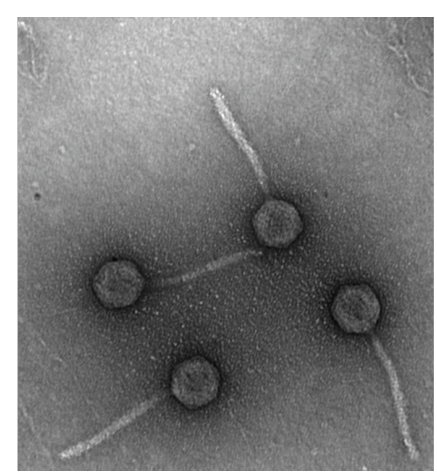

JBD44a

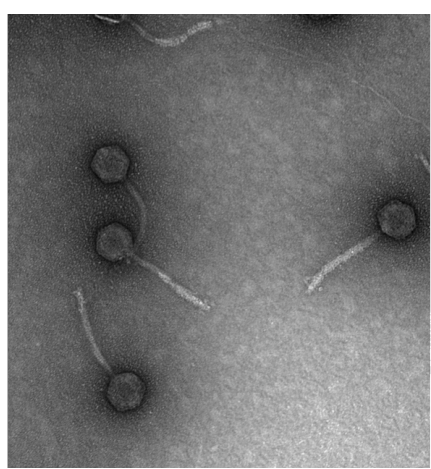

JBD4

Figure 1. B.

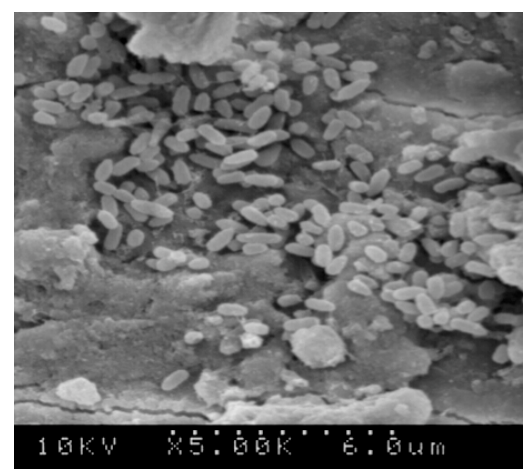

Figure 2.

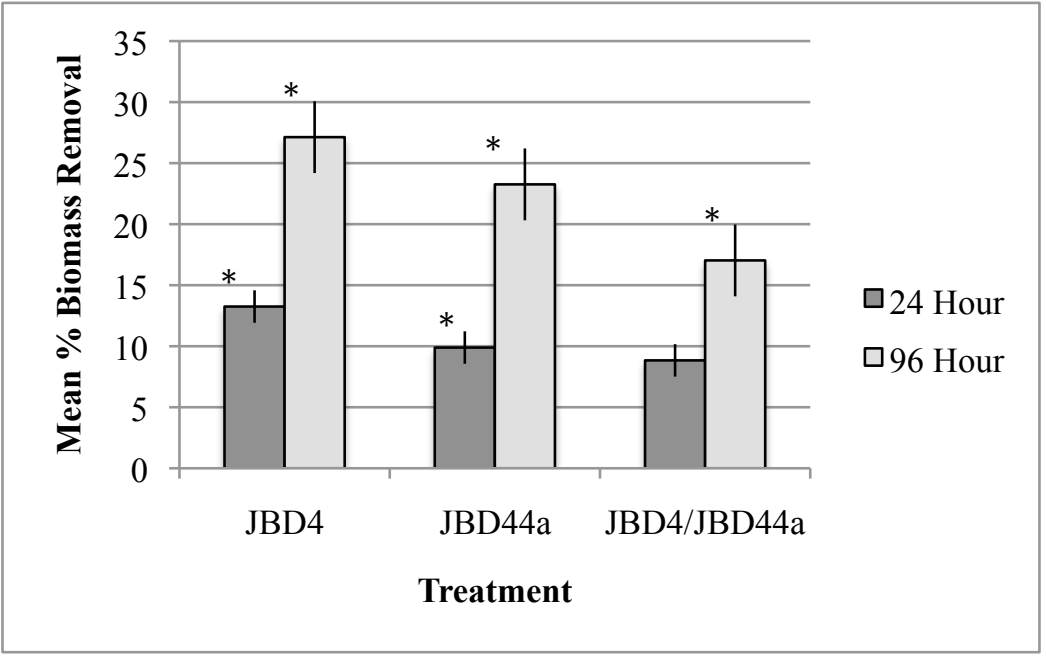




\section{Discussion}

The human oral microbiome consists of over 800 identifiable species (134-136). Many of these have reportedly been found in the root canal and periapical tissues of teeth with endodontic infections $(32,35,137-143)$. While most infections caused by these microorganisms can be readily eliminated by current endodontic protocols, there are instances when the infection persists. Bacteria that are present in a biofilm and resistant to current disinfection protocols (78-89) are one of the causes of persistent infection (144-146). The most significant evasion from the host defense system is the microbial arrangement in a biofilm (31) and it is also the most important survival mechanism for bacteria (21). Tronstad et al. observed periapical plaque in teeth refractory to endodontic treatment (146). Surgical intervention was performed and bacteria that were held together by an extracellular material were noted in $73 \%$ of the specimens. Bacterial biofilm may explain the ability to sustain disease even after conventional interventions. Noiri et al. also analyzed surgical specimens and $82 \%$ had extraradicular biofilms (145). Reduction of biofilm is therefore significant as it may increase the prognosis of endodontic treatment by limiting the microbial causes of disease.

Unlike endodontic management of primary infections, the treatment of persistent infection often can be more specific and directed towards the elimination of a lesser number of identifiable species $(25,61)$. One species identified as a cause of persistent disease in endodontics is Pseudomonas aeruginosa (63-65,102-105). Additionally, $P$. aeruginosa being a Gram-negative opportunistic pathogen with excellent ability to form biofilm, will serve as an excellent model organism to assess the antimicrobial efficacy of 
bacteriophages. For this reason and the reported limited, but modestly successful use of phage therapy in the management of antibiotic-resistant $P$. aeruginosa infections in vivo $(129,130)$, this microorganism was selected as the target species in this study. A report by O'Toole et al. in 1986 (147) showed that $P$. aeruginosa biofilm having a dense monolayer of cells punctuated with numerous micro-colonies could be successfully grown at $25-37^{\circ} \mathrm{C}$ on polystyrene plastic in 8 hours. In this study, $P$. aeruginosa biofilm was grown on the pegs of polystyrene microplates, which provided a readily available substrate for the study.

P. aeruginosa biofilms grown for 24 and 96 hours were selected for use as substrates based upon a 2010 study published by Wolcott et al. (148) which showed 24h $P$. aeruginosa biofilms were susceptible to selected antibiotics and that increased resistance to antibiotic was typical of those that were grown for $48 \mathrm{~h}$ or longer $(147,149,150)$. Indirectly this also supported the use of the $96 \mathrm{~h}$ biofilm, the second substrate used in this study. At twice the age of a $48 \mathrm{~h}$ biofilm, it was felt that at $96 \mathrm{~h}$ the biofilm would be representative of one where antibiotic therapy would have little chance for success, making phage therapy a reasonable conservative treatment option. The $96 \mathrm{~h}$ biofilm was confirmed to be significantly different from the $24 \mathrm{~h}$ biofilm. This conclusion was based on visual confirmation of differences in biofilm morphology and consistency as well as crystal violet adherence quantified using a plate reader. As a biofilm ages there is a proportionate increase in the ratio of dead to live cells within the biomass. This makes cells in the deeper layers more difficult to reach because phages bind equally to receptor sites on both live and dead cells. This effectively reduces their infection rate of viable cells (125). In addition, bacteria in older biofilms metabolize at a lower rate than those 
that are younger ones, especially if the bacteria are present in the deeper layers where the availability of oxygen and other nutrients is limited. As phage infection and phage life cycle are both dependent upon the growth stage of the host cell $(119,151)$, it would be expected that the more slowly metabolizing cells present in older biofilms would demonstrate an increased degree of phage resistance (152). Since the reduction in biomass of the $96 \mathrm{~h}$ biofilm in this study was comparable to that of the $24 \mathrm{~h}$ biofilm after phage treatment, consideration had to be given as to why the expected outcome did not occur. It was suspected that this resulted from a variance in which the $96 \mathrm{~h}$ biofilm was grown, a variance that did not allow it to reach sufficient maturity to express the phage resistance expected. Another reason for the choice of a $24 \mathrm{~h}$ treatment time was based on a report that even at $48 \mathrm{~h}$, release of endotoxin by lysed bacteria causes injury to the host cell (153). This may have affected the ability to recover viable bacteria post-treatment for phage efficacy quantification. Studies that had used successfully longer or multiple treatment times $(129,130,132)$ may have used a variant phage. The $24 \mathrm{~h}$ phage treatment time used in this study allowed for comparison with other research that also used this interaction period $(37,39,40,42,132,149)$.

The choice of phages used in this study, JBD4 and JBD44a, was based upon our preliminary data that showed that these particular phages, selected from a collection of 80 isolated $P$. aeruginosa phages, had the potential for reducing $P$. aeruginosa biomass. The chosen phages resulted in halo formation during plaquing assays, indicating their possible ability reduce exopolysaccharide and to effectively reduce a bacterial biofilm. A combination, as well as use of single phages, was tested because previous clinical trials had reported the successful use of phage combination in the treatment of human and 
animal $P$. aeruginosa infections $(129,130)$. When the combination of phages proved to be less effective than the use of just one, it was theorized that they could share a common genomic sequence. Since no bacterial clearance by either phage had been detected in JBD4 or JBD44a $P$. aeruginosa lysogens, the infection by one had prevented infection by the other, proving this theory correct. Destruction of the matrix is an important aspect in phage selection because the matrix represents a physical impediment but also serves as a reservoir for proteolytic enzymes and endoglucanases that can cause phage inactivation. Phages that produce enzymes that disrupt the matrix are more successful at penetrating biofilm and reaching the deep cells of the biofilm at therapeutic concentrations (152). Disrupting the biofilm without harming dentin substrate would have the combined benefit of allowing increased antimicrobial penetration during endodontic disinfection.

A phage concentration of $1 \times 10^{5} \mathrm{pfu} / \mathrm{mL}$ had been used in the Wright study (130) and 2 X $10^{8} \mathrm{pfu} / \mathrm{mL}$ concentration was used in the Paisano study (132). Our preliminary data showed that there was reproducibility of biomass reduction at the higher concentrations and as a result, an initial concentration of $2 \times 10^{7} \mathrm{pfu} / \mathrm{mL}$ of JBD4 and JBD44a was selected. It is possible that in the Wright study the gene segment coding for polysaccharide depolymerases, DNAse, or protease enzymes carried by the phage could have been sufficiently different than the ones used in this study to account for the decrease in concentration that still allowed it to generate a similar therapeutic effect (152). Studies that examined the post-treatment phage concentrations $(35,36,39)$ found a significantly higher phage concentration compared to the initial concentration. The lack of significance between the pre-treatment phage concentration and the post-treatment 
concentrations in this study could have been a result of the sampling methods used and their ability to recover the phages.

One challenge identified with the microplate assay was determining the cause of crystal violet absorbance to the polystyrene pegs of the microplates. The negative charge of $P$. aeruginosa and the biofilm both bind to the crystal violet dye, hence the quantification of biomass during the microplate assay. Until the answer to the binding of the dye to polystyrene can be explained, this assay cannot effectively be used to determine phage efficacy. The use of polystyrene microplates was modeled after the Calgary biofilm device created by Ceri et al. in 1999 (154) that was developed to test the antibacterial susceptibility of biofilms in general. Growth curves demonstrated that biofilms of a predetermined size could consistently be formed on the device at specific time points with no significant differences on each of the 96 pegs. The use of a crystal violet assay to quantify biomass destruction was modeled after a microtitre plate assay created by Knezevic and Petrovic in 2008 (150). The assay used in the current study was modified to adjust for the biofilm growth on the pegs of the lid rather than the wells but was quantified in a similar manner with a plate reader. The assay in the current study used $70 \%$ ethanol to remove the stained biofilm, rather than the $95 \%$ ethanol recommended by O'Toole et al. (147) as the higher concentration of ethanol was found in preliminary experiments to have too high an evaporation rate. Preliminary experiments showed that the incubation time of $1 \mathrm{~h}$ in the ethanol provided the most consistent results.

Several problems were encountered when phage therapy was assessed as a disinfection option for the root canal of $P$. aeruginosa infected extracted teeth. Because a lab pipette was used to place the phage suspension into the root canal, delivery of the phage to apical 
third of the root canal could not be assured; however, preliminary work using scanning electron microscopy analysis of infected teeth showed $P$. aeruginosa existed throughout the length of the canal. The lack of evidence of consistent biofilm formation in the apical third of the root canal could explain the relative ineffectiveness of phage therapy in the tooth model. Other delivery systems should therefore be explored before the clinical application of phage therapy is to be tested. These could include, but not limited to, the use of sonic or ultrasonic vibration, a pre-fitted gutta percha used in a plunging action, or a lentulo spinner. The differences in the surfaces of the two test models may also explain the difference in the results between the twp parts of the study. The microwell plate assay may provide a better adhesive surface for the attachment of biofilm compared to dentin as the polystyrene surface is hydrophobic in nature versus the hydrophilic surface of dentin.

One of the sampling methods used in this study was paper point absorption. This method was chosen based on previous studies $(6,31,60,63,65,104,132,155)$ that used paper points as their main method to extract the contents inside the root canal system. The paper points were specifically chosen to address the planktonic bacteria within the root canal. Round burs were also used in an attempt to show the presence of both bacteria and the bacteriophages attached to the dentin surface as well as showing penetration inside the dentinal wall of the root canal. Further studies are needed to compare different sampling methods and identify a sampling method that adequately removed both planktonic cells and attached biofilm structure. Other methods of consideration include hand files, rotary files, and sonic or ultrasonic agitation combined with paper point sampling. Research is needed to determine the depth of penetration of the phages into dentin and their sustainability inside the dentin. 
This study represents a fraction of the scope of research that needs to be done to understand the potential role of bacteriophages in endodontic therapy. Further investigation into the most effective phage, or combination of phages, against $P$. aeruginosa and other microorganisms that are also responsible for persistent endodontic infections is needed. Bacteriophage genetic engineering and characterizations require further research to determine the optimal treatment parameters against each type of endopathic bacteria. Methods of delivering the bacteriophages using different media into the root canal have to be assessed to optimize the distribution of the phages within the complex anatomy of the root canal system. More research is necessary to determine whether phage therapy will someday become a reasonable treatment choice for persistent endodontic disease. 


\section{Conclusions}

It was concluded that addition of JBD4, JBD44a, and a combination of both phages significantly reduced the biomass of 24 and $96 \mathrm{~h} P$. aeruginosa biofilms grown on microwell plates. Phages were able to significantly reduce more $96 \mathrm{~h}$ biomass compared to $24 \mathrm{~h}$.

Phage addition did not produce significant reduction of viable bacterial counts for 24 or 96h $P$. aeruginosa biofilms grown in extracted root canal models.

Post-treatment phage concentrations were higher than pre-treatment loading concentrations. 


\section{References}

1. Hyman P. Bacteriophages and nanostructured materials. Adv Appl Microbiol 2012;78:55-73.

2. Barrow PA, Soothill JS. Bacteriophage therapy and prophylaxis: rediscovery and renewed assessment of potential. Trends Microbiol 1997;5:268-71.

3. Abedon ST, Kuhl SJ, Blasdel BG, Kutter EM. Phage treatment of human infections. Bacteriophage 2011;1:66-85.

4. Marvin DA. Filamentous phage structure, infection and assembly. Curr Opin Struct Biol 1998;8:150-8.

5. Kakehashi S, Stanley HR, Fitzgerald RJ. The effects of surgical exposures of dental pulps in germ-free and conventional laboratory rats. Oral Surg Oral Med Oral Pathol 1965;20:340-9.

6. Möller AJ. Microbiological examination of root canals and periapical tissues of human teeth Methodological studies (thesis). Odontol Tidskr 1966;74:1-380.

7. Pitt Ford TR. The effects on the periapical tissues of bacterial contamination of the filled root canal. Int Endod J 1982;15:16-22.

8. Byström A, Sundqvist G. The antibacterial action of sodium hypochlorite and EDTA in 60 cases of endodontic therapy. Int Endod J 1985;18:35-40.

9. Byström A, Happonen RP, Sjögren U, Sundqvist G. Healing of periapical lesions of pulpless teeth after endodontic treatment with controlled asepsis. Endod Dent Traumatol 1987;3:58-63.

10. Ray HA, Trope M. Periapical status of endodontically treated teeth in relation to the technical quality of the root filling and the coronal restoration. Int Endod $\mathrm{J}$ 1995;28:12-18.

11. Tronstad L, Asbjørnsen K, Døving L, Pedersen I, Eriksen HM. Influence of coronal restoration on the periapical health of endodontically treated teeth. Endod Dent Traumatol 2000;16:218-21.

12. Kirkevang LL, Ørstavik D, Hörsted-Bindslev, Wenzel A. Periapical status and quality of root fillings and coronal restorations in a Danish population. Int Endod J 2000;33:509-15.

13. Dugas NN, Lawrence HP, Teplitsky PE, Pharoah MJ, Friedman S. Periapical health and treatment quality assessment of root-filled teeth in two Canadian populations. Int Endod J 2003;36:181-92. 
14. Ng YL, Mann V, Rahbaran S, Lewsey J, Gulabivala K. Outcome of primary root canal treatment: systematic review of the literature-Part 1. Int Endod $\mathrm{J}$ 2007;40:921-39.

15. Ng YL, Mann V, Gulabivala K. A prospective study of the factors affecting outcomes of nonsurgical root canal treatment- Part 1: Periapical health. Int Endod J 2011;44:583-609.

16. Salehrabi R, Rotstein I. Endodontic treatment outcomes in a large patient population in the UA: An epidemiological study. J Endod 2004;30:846-50.

17. De Chevigny C, Dao TT, Basrani BR, Marquis V, Farzaneh M, Abitol S, Friedman S. Treatment outcome in Endodontics: The Toronto study-Phase 4: Initial treatment. J Endod 2008;34:258-63.

18. Nair PNR. Pathogenesis of apical periodontitis and the causes of endodontic failures. Crit Rev Oral Biol Med 2004;15:348-81.

19. Nair PNR. Cholesterol as an aetiological agent in endodontic failures-a review. Aust Endod J 1999;25:19-26.

20. Nair PNR, Sjörgen U, Krey G, Kahnberg KE, Sundqvist G. Intraradicular bacteria and fungi in root-filled, asymptomatic human teeth with therapy-resistant periapical lesions: a long-term light and electron microscopic follow-up study. $\mathbf{J}$ Endod 1990;16:580-8.

21. Chávez de Paz L. Redefining the persistent infection in root canals: possible role of biofilm communities. J Endod 2007;33:652-62.

22. Swanson K, Madison S. An evaluation of coronal leakage in endodontically treated teeth. Part 1: Time periods. J Endod 1987;13:56-9.

23. Madison S, Swanson K, Chiles SA. An evaluation of coronal microleakage in endodontically treated teeth. Part 2: Sealer types. J Endod 1987;12:109-12.

24. Torabinejad M, Ung B, Kettering JD. In vitro penetration of coronally unsealed endodontically treated teeth. J Endod 1990;16:566-9.

25. Siqueira JF, Rôças IN. Clinical implications and microbiology of bacterial persistence after treatment procedures. J Endod. 2008;34:1291-1301.

26. Shuping GB, Ørstavik D, Sigurdsson A, Trope M. Reduction of intracanal bacteria using nickel-titanium rotary instrumentation and various medications. $\mathrm{J}$ Endod 2000: 26: 751-755.

27. Peters LB, Van Winkelhoff AJ, Buijs JF, Wesselink PR. Effects of 
instrumentation, irrigation and dressing with calcium hydroxide on infection in pulpless teeth with periapical bone lesions. Int Endod J 2002; 35: 13-21.

28. Peters OA, Peters CI, Schönenberger K, Barbakow F. ProTaper rotary root canal preparation: effects of canal anatomy on the final shape analyzed by micro CT. Int Endod J 2003;36:86-92.

29. Haapasalo M, Udnaes T, Endal U. Persistent, recurrent, and acquired infection of the root canal system post-treatment. Endo Topics 2003;6:29-56.

30. Ricucci D, Siqueira JF. Recurrent apical periodontitis and late endodontic treatment failure related to coronal leakage: a case report. J Endod 2011;37:11715.

31. Siqueira JF. Aetiology of root canal treatment failure: why well-treated teeth can fail. Int Endod J 2001;34:1-10.

32. Sundqvist G, Figdor D, Persson S, Sjörgen U. Microbial analysis of teeth with failed endodontic treatment and the outcome of conservative re-treatment. Oral Surg Oral Med Oral Path Oral Radiol Endod 1998;85:86-93.

33. Jungermann GB, Burns K, Nandakumar R, Tolba M, Venezia RA, Fouad AF. Antibiotic resistance in primary and persistent endodontic infections. J Endod 2011;37:1337-44.

34. Sundqvist G. Taxonomy, ecology, and pathogenicity of the root canal flora. Oral Surg Oral Med Oral Path Oral Radiol Endod 1994;78:522-30.

35. Sundqvist G, Johansson E, Sjörgen U. Prevalence of black-pigmented bacteroids species in root canal infections. J Endod 1989;15:13-19.

36. Byström A, Sundqvist G. Bacteriological evaluation of the efficacy of mechanical root canal instrumentation in endodontic therapy. Scand J Dent Res 1981;89:3218.

37. Haapasalo M. Bacteroides spp. in dental root canal infections. Endod Dent Traumatol 1989;5:1-10.

38. Baumgartner JC, Falker WA. Bacteria in the apical $5 \mathrm{~mm}$ of infected root canals. J Endod1991;17:380-3.

39. Hancock HHI, Sigurdsson AD, Trope MB, Moiseiwitsch JB. Bacteria isolated after unsuccessful endodontic treatment in a North American population. Oral Surg Oral Med Oral Pathol 2001;91:579-86.

40. Bergenholtz G. Micro-organisms from necrotic pulp of traumatized teeth. Odontol 
Revy 1974;25:347-58.

41. Brauner AW, Conrads G. Studies into the microbial spectrum of apical periodontitis. Int Endod J 1995;28:244-8.

42. Brook I, Frazier EH, Gher ME. Aerobic and anaerobic microbiology of periapical abscess. Oral Microbiol Immunol 1991;6:123-5.

43. Fouad AF, Barry J, Caimano M, Clawson M, Zhu Q, Carver R, Hazlett K, Radolf JD. PCR-based identification of bacteria associated with endodontic infections. J Clin Microbiol 2002;40:3223-31.

44. Haapasalo M, Ranta H, Ranta K, Shah H. Black pigmented Bacteroides spp in human apical periodontitis. Infect Immun 1986;53:149-53.

45. Haapasalo M. Bacteroides buccae and related taxa in necrotic root canal infections. J Clin Microbiol 1986;24:940-4.

46. Hashioka K, Yamasaki M, Nakane A, Horiba N, Nakamura H. The relationship between clinical symptoms and anaerobic bacteria from infected root canals. J Endod 1992;18:558-61.

47. Kantz WE, Henry CA. Isolation and classification of anaerobic bacteria from intact pulp chambers of non-vital teeth in man. Arch Oral Biol 1974;19:91-6.

48. Khemaleelakul S, Baumgartner JC, Pruksakorn S. Identification of bacteria in acute endodontic infections and their antimicrobial susceptibility. Oral Surg Oral Med Oral Pathol 2002;94:746-55.

49. von Konow L, Nord CE, Nordenram A. Anaerobic bacteria in dentoalveolar infections. Int J Oral Surg 1981;10:313-22.

50. Munson MA, Pitt-Ford T, Chong B, Weightman A, Wade WG. Molecular and cultural analysis of the microflora associated with endodontic infections. J Dent Res 2002;81:761-6.

51. Oguntebi B, Slee AM, Tanzer JM, Langeland K. Predominant microflora associated with human dental periapical abscesses. J Clin Microbiol 1982;15:9646.

52. Siqueira JF Jr, Rôças IN, Souto R, Uzeda M, Colombo AP. Microbiological evaluation of acute periradicular abscesses by DNA-DNA hybridization. Oral Surg Oral Med Oral Pathol 2001;92:451-7.

53. Siqueira JF, Rôças IN, Souto R, de Uzeda M, Colombo AP. Actinomyces species, streptococci, and Enterococcus faecalis in primary root canal infections. J Endod 
2002;28:168-72.

54. Siqueira JF Jr, Rôças IN. Dialister pneumosintes can be a suspected endodontic pathogen. Oral Surg Oral Med Oral Pathol 2002;94:494-8.

55. de Sousa EL, Ferraz CC, Gomes BP, Pinheiro ET, Teixeira FB, Souza-Filho FJ. Bacteriological study of root canals associated with periapical abscesses. Oral Surg Oral Med Oral Pathol 2003;96:332-9.

56. Van Winkelhoff AJ, Carlee AW, de Graaff J. Bacteroides endodontalis and other black-pigmented Bacteroides species in odontogenic abscesses. Infect Immun 1985;49:494-7.

57. Wittgow WC Jr, Sabiston CB Jr. Microorganisms from pulpal chambers of intact teeth with necrotic pulps. J Endod 1975;1:168-71.

58. Peciuliene V, Balciuniene I, Eriksen HM, Haapasalo M. Isolation of Enterococcus faecalis in previously root filled canals in a Lithuanian population. J Endod 2000;26:593-5.

59. Peciuliene V, Reynaud A, Balciuniene I, Haapasalo M. Isolation of yeasts and enteric bacteria in root-filled teeth with chronic apical periodontitis. Int Endod J 2001;34:429-34.

60. Kalfas S, Figdor D, Sundqvist G. A new bacterial species associated with failed endodontic treatment: identification and description of Actinomyces radicidentis. Oral Surg Oral Med Oral Pathol Oral Radiol Endod 2001;92:208-14.

61. Chávez de Paz LE, Molander A, Dahlén G. Gram-positive rods prevailing in teeth with apical periodontitis undergoing root canal treatment. Int Endod $\mathrm{J}$ 2004;37:579-87.

62. Happonen RP, Söderling E, Viander M, Linko-Kettunen L, Pelliniemi LJ. Immunocytochemical demonstration of Actinomyces species and Arachnia propionica in periapical infections. J Oral Path 1985;14:405-13.

63. Tronstad L, Barnett F, Riso K, Slots J. Extraradicular endodontic infections. Dent Traumatol 1987;3:86-90.

64. Ranta K, Haapasalo M, Ranta H. Monoinfection of root canal with Pseudomonas aeruginosa. Endod Dent Traumatol 1988;4:269-72.

65. Siren EK, Haapasalo MPP, Ranta K, Salmi P. Microbiological findings and clinical treatment procedures in endodontic cases selected for microbiological investigation. Int Endod J. 1997;30:91-5. 
66. Ng YL, Mann V, Gulabivala K. Outcome of secondary root canal treatment: a systematic review of the literature. Int Endod J 2008;41:1026-46.

67. Ng YL, Mann V, Gulabivala K. A prospective study of the factors affecting outcomes of non-surgical root canal treatment: part 1: periapical health. Int Endod J 2011;44:583-609.

68. Barone C, Dao TT, Basrani BB, Wang N, Friedman S. Treatment outcomes in endodontics: The Toronto study-Phases 3,4, and 5: Apical surgery. J Endod 2010;36:28-35.

69. von Arx T, Jensen SS, Hänni S, Friedman S. Five-year longitudinal assessment of the prognosis of apical surgery. J Endod 2012;38:570-9.

70. Cornelissen A, Ceyssens PJ, T'Sen J, Praet HV, Noben JP, Shaburova OV, et al. The T7-Related Pseudomonas putida Q15 Displays Virion-Associated Biofilm Degradation Properties. Plos One 2011;6:e18597.

71. Costerton, JW, Lewandowski Z, DeBeer D, Caldwell D, Korber D, James, G. 1994. Biofilms, the customized microniche. J Bacteriol 1994;176:2137-42.

72. Schaul G, Griebe T, Flemming HC. Steps in biofilm sampling and characterization in biofouling cases. In: Flemming, HC, Szewyk U, Griebe T. (Eds.), Biofilms-Investigative Methods and Applications. Technomic, Basel, 2000;1-22.

73. Davies DG, Chakrabarty AM, Geesey GG. Exopolysaccharide production in biofilms: substratum activation of alginate gene expression by Pseudomonas aeruginosa. Appl Environ Microbiol. 1993;59:1181-6.

74. Walker JT, Marsh PD. A review of biofilms and their role in microbial contamination of dental unit water systems (DUWS). Inter Biodeter Biodegrad 2004;54:87-98.

75. Ricucci D, Siqueira JF. Biofilms and apical periodontitis: study of prevalence and association with clinical and histological findings. J Endod 2010;36:1277-88.

76. Siqueira JF, Rôças IN. Community as the unit of pathogenicity: An emerging concept as to the microbial pathogenesis of apical periodontitis. Oral Surg Oral Med Oral Path Oral Rad Endod 2009:107:870-8.

77. Carr GB, Schwartz RS, Schaudinn C, Gorur A, Costerton JW. Ultrastructural examination of failed molar retreatment with secondary apical periodontitis: an examination of endodontic biofilms in an endodontic retreatment failure. J Endod 2009;35:1303-9. 
78. Fimple JL, Fontana CR, Foschi F, et al. Photodynamic treatment of endodontic polymicrobial infection in vitro. J Endod 2008;34:728-34.

79. George S, Kishen A. Effect of tissue fluids on hydrophobicity and adherence of Enterococcus faecalis to dentin. J Endod 2007;33:1421-5.

80. Soukos NS, Chen PS, Morris JT, et al. Photodynamic therapy for endodontic disinfection. J Endod 2006;32:979-84.

81. Williamson AE, Cardon JW, Drake DR. Antimicrobial susceptibility of monoculture biofilms of a clinical isolate of Enterococcus faecalis. J Endod 2009;35:95-7.

82. Burleson A, Nusstein J, Reader A, et al. The in vivo evaluation of hand/rotary/ultrasound instrumentation in necrotic, human mandibular molars. $\mathrm{J}$ Endod 2007;33:782-7.

83. van der Sluis LW, Versluis M, Wu MK, et al. Passive ultrasonic irrigation of the root canal: a review of the literature. Int Endod J 2007;40:415-26.

84. Seal GJ, Ng YL, Spratt D, et al. An in vitro comparison of the bactericidal efficacy of lethal photosensitization or sodium hypochlorite irrigation on Streptococcus intermedius biofilms in root canals. Int Endod J 2002;35:268-74.

85. del Carpio-Perochena AE, Bramante CM, Duarte MAH, Cavenago BC, VillasBoas MH, Graeff MS, et al. Biofilm dissolution and cleaning ability of different irrigant solutions on intraorally infected dentin. J Endod 2011;37:1134-8.

86. Sena NT, Gomes BP, Vianna ME, et al. In vitro antimicrobial activity of sodium hypochlorite and chlorhexidine against selected single-species biofilms. Int Endod J 2006;39:878-85.

87. Bryce G, O'Donnell D, Ready D, Ng Y, Pratten J, Gulabivala K. Contemporary root canal irrigants are able to disrupt and eradicate single- and dual-species biofilms. J Endod 2009;35:1243-8.

88. Spratt DA, Pratten J, Wilson M, et al. An in vitro evaluation of the antimicrobial efficacy of irrigants on biofilms of root canal isolates. Int Endod J 2001;34:300-7.

89. Chávez LE, Bergenholtz G, Svensäter G. The effects of antimicrobials on endodontic biofilm bacteria. J Endod 2010;36:70-7.

90. Siqueira JF Jr, Rôças IN, Favieri A, Lima KC. Chemomechanical reduction of the bacterial population in the root canal after instrumentation and irrigation with $1 \%$, $2.5 \%$, and 5.25\% sodium hypochlorite. J Endod 2000;26:331-4. 
91. D'Arcangelo C, Varvara G, De Fazio P. An evaluation of the action of different root canal irrigants on facultative aerobic-anaerobic, obligate anaerobic, and microaerophilic bacteria. J Endod 1999;25:351-3.

92. White RR, Hays GL, Janer LR. Residual antimicrobial activity after canal irrigation with chlorhexidine. J Endod 1997;23:229-31.

93. Dunavant TR, Regan JD, Glickman GN, Solomon ES, Honeyman AL. Comparative evaluation of endodontic irrigants against Enterococcus faecalis biofilms. J Endod 2006;32:527-31.

94. Ørstavik D, Haapasalo M. Disinfection by endodontic irrigants and dressings of experimentally infected dentinal tubules. Endod Dent Traumatol 1990;6:142-9.

95. Ryan KJ, Ray CG, editors. Sherris Medical Microbiology. $4^{\text {th }}$ ed.: McGraw Hill; 2004.

96. Anzai et al. Phylogenetic affiliation of the pseudomonads based on 16S rRNA sequence. Int J Syst Evol Microbiol 2000;50:1563-89.

97. King EO, Ward MK, Raney DE. Two simple media for the demonstration of pyocyanin and fluorescein. J Lab Clin Med 1954;44:301-7.

98. Cornelis P, editor. Pseudomonas: Genomics and Molecular Biology. Caister Academic Press, 2008.

99. Iglewski BH. Pseudomonas. In: Baron S. et al. editors. Baron's Medical Microbiology. $4^{\text {th }}$ ed.: Univ of Texas Medical Branch; 1996.

100.Botzenhardt K, Doring G. Ecology and epidemiology of Pseudomonas aeruginosa. Pseudomonas aeruginosa as an Opportunistic Pathogen; 1993:1-7.

101. Yang L, Hu Y, Liu Y, Zhang J, Ulstrup J Molin S. Distinct roles of extracellular polymeric substances in Pseudomonas aeruginosa biofilm development. Environ Microbiol 2011;13:1705-17.

102.Fujii R, Saito Y, Tokura Y, Nakagawa KI, Okuda K, Ishihara K. Characterization of bacteria flora in persistent apical periodontitis lesions. Oral Microbiol Immunol 2009;24:502-5.

103. Siqueira JF, Rôças IN. Clinical implications and microbiology of bacterial persistence after treatment procedures. J Endod. 2008;34:1291-1301.

104. Cheung GSP, Ho MWM. Microbial flora of root canal-treated teeth associated with asymptomatic periapical radiolucent lesions. Oral Microbiol Immunol 2001;16:332-7. 
105. Molander A, Reit C, Dahlén G, Kvist T. Microbiological status of root-filled teeth with apical periodontitis. Inter Endod J 1998;31:1-7.

106. Tsatsas B, Tzamouranis A, Mitsis F. An examination of root canals before filling. Inter Endod J 1974;7:78-80.

107.Nord CE, Sjöberg L, Wadström T. Pseudomonas aeruginosa in oral infections. Acta Odont Scand 1972;30:371-81.

108. Raphael D, Wong TA, Moodnik R, Borden BG. The effect of temperature on the bactericidal efficiency of sodium hypochlorite. J Endod 1981;7:330-4.

109.Leonardo MR, da Silva LAB, Filho MT, Bonifacio KC, Ito IY. In vitro evaluation of antimicrobial activity of sealers and pastes used in endodontics. J Endod 200;26:391-4.

110.Estrela C, Pimenta FC, Ito IY, Bammann LL. In vitro determination of direct antimicrobial effect of calcium hydroxide. J Endod 1998;24:15-7.

111. Garcez AS, Ribeiro MS, Tegos GP, Nunez SC, Jorge AOC, Hamblin MR. Antimicrobial photodynamic therapy combined with conventional endodontic treatment to eliminate root canal biofilm infection. Lasers in Surgery 2007;39:5966.

112. Kayaoglu G, Ørstavik D. Virulence factors of Enteroccocus faecalis: Relationship to endodontic disease. Crit Rev Oral Bio Med 2004;15:308-20.

113. Wang L, Dong M, Zheng J, Song Q, Yin W, Li J, Niu W. Relationship of biofilm formation and gelE gene expression in Enterococcus faecalis recovered from root canals in patients requiring endodontic retreatment. J Endod 2011;37:631-6.

114. Zhu X, Wang Q, Zhang C, Cheung GSP, Shen Y. Prevalence, phenotype, and genotype of Enterococcus faecalis isolated from saliva and root canals in patients with persistent apical periodontitis. J Endod 2010;36:1950-5.

115.Donlan R. Preventing biofilms of clinically relevant organisms using bacteriophage. Trend Microbiol 2009;17:66-72.

116. Clark JR, March JB. Bacteriophages and biotechnology: vaccines, gene therapy and antimicrobials. Trends Biotechnol 2006;24:212-8.

117. Bayer ME, Thurow H, Bayer MH. Penetration of the polysaccharide capsule of Escherichia coli (Bil 62/42) by bacteriophage K29. Virol 1979;94;95-118.

118. Górski A, Miedzybrodzki R, Borysowski J, Weber-Dabrowska B, Lobocka M, 
Fortuna W, Letkiewicz S, Zimecki M, Filby G. Bacteriophage therapy for the treatment of infections. Curr Opin Investig Drugs 2009;10:766-74.

119. Sillankorva S, Pleteneva E, Shaburova O, Santos S, Carvalho C, Azeredo J, et al. Salmonella Enteritidis bacteriophage candidates for phage therapy of poultry. J Appl Microbiol 2010;108:1175-86.

120. Sharma M, Patel JR, Conway WS, Ferguson S, Sulakvelidze A. Effectiveness of bacteriophages in reducing Escherichia coli O157:H7 on fresh-cut cantaloupes and lettuce. J Food Prot 2009;72:1481-5.

121.Dąbrowska K, Skaradziński G, Kurzępa A, Owczarek B, Zaczek M, WeberDąbrowska B, et al. The effects of staphylococcal bacteriophage lysates on cancer cells in vitro. Clin Exp Med 2010;10:81-5.

122. Rhoads DD, Wolcott RD, Kuskowski MA, Wolcott BM, Ward LS, Sulakvelidze A. Bacteriophage therapy of venous leg ulcers in humans: results of a phase 1 safety trial. J Wound Care 2009;18:237-43.

123. Schmitz N, Dietmeier K, Bauer M, Maudrich M, Utzinger S, Muntwiler S, et al. Displaying Fel d1 on virus-like particles prevents reactogenicity despite greatly enhanced immunogenicity: a novel therapy for cat allergy. J Exp Med 2009;206:1941-55.

124.Zimecki M, Artym J, Kocieba M, Weber-Dabrowska B, Borysowski J, Górski A. Prophylactic effect of bacteriophages on mice subjected to chemotherapy-induced immunosuppression and bone marrow transplant upon infection with Staphylococcus aureus. Med Microbiol Immunol 2010;199:71-9.

125. Sutherland IW, Hughes KA, Skillman LC, Tait K. The interaction of phage and biofilms. FEMS Microbiol Lett 2004;232:1-6.

126. Hughes KA, Sutherland IW, Clark J, Jones MV. Bacteriophage and associated polysaccharide depolymerases-novel tools for study of bacterial biofilms. J Appl Microbiol 1998;85:583-90.

127. Glonti T, Chanishvili N, Taylor PW. Bacteriophage-derived enzyme that depolymerases the alginic acid capsule associated with cystic fibrosis isolates of Pseudomonas aeruginosa. J Appl Microbiol 2009;107:1-8.

128.Lu TK, Collins JJ. Dispersing biofilms with engineered enzymatic bacteriophage. Proc Nat Acad Sci USA 2007;104:11197-202.

129. Hawkins C, Harper D, Burch D, Änggård E, Soothill J. Topical treatment of Pseudomonas aeruginosa otitis of dogs with a bacteriophage mixture: A before/after clinical trial. Veter Micro 2010;146:309-13. 
130. Wright, A, Hawkins, CH, Änggård E, Harper, DR. A controlled clinical trial of a therapeutic bacteriophage preparation in chronic otitis due to antibiotic-resistant Pseudomonas aeruginosa; a preliminary report of efficacy. Clin Otolaryngol 2009;34,:349-57.

131. Shultz EW. Bacteriophage: A possible therapeutic aid in dental infections. J Dent Res 1932;12:295-310.

132. Paisano AF, Spira B, Cai S, Bombana AC. In vitro antimicrobial effect of bacteriophages on human infected dentin with Enterococcus faecalis ATCC 29212. Oral Microbiol Immunol 2004;19:327-30.

133. Stevens RH, Porras OD, Delisle AL. Bacteriophages induced from lysogenic root canal isolates of Enterococcus faecalis. Oral Microbiol Immunol 2009;24:278-84.

134. Dewhirst FE, Chen T, Izard J, Paster BJ, Tanner ACR, Yu WH, et al. The human oral microbiome. J Bacteriol 2010;192:5002-17.

135. Aas JA, Paster BJ, Stokes LN, Olsen I, Dewhirst FE. Defining the normal bacterial flora of the oral cavity. J Clin Microbiol 2005;43:5721-32.

136. Keijser BJ, Zaura E, Huse SM, van der Vossen JM, Schuren FH, Montijn RC et al. Pyrosequencing analysis of the oral microflora of healthy adults. J Dent Res 2008;87:1016-20.

137. Sundqvist G. Association between microbial species in dental root canal infections. Oral Microbiol Immunol 1992;7:257-62.

138. Sundqvist G. Ecology of the root canal flora. J Endod 1992;18:427-30.

139. Abou-Rass M, Bogen G. Microorganisms in closed periapical lesions. Int Endod J 1998;31:39-47.

140. Machado de Oliveira JC, Siqueira JF, Rôças IN, Baumgartner JC, Xia T, Peixoto RS, Rosado AS. Bacterial community profiles of endodontic abscesses from Brazilian and USA subjects as compared by denaturing gradient gel electrophoresis analysis. Oral Microbiol Immunol 2007;22:14-8.

141.Fabricius L, Dahlén G, Ohman AE, Möller AJ. Predominate indigenous oral bacteria isolated from infected root canals after varied times of closure. Scand $\mathrm{J}$ Dent Res 1982;90:134-44.

142. Fabricius L, Dahlén G, Holm SE, Möller AJ. Influence of combinations of oral bacteria on periapical tissues on monkeys. Scan J Dent Res 1982;90:200-6. 
143. Conrads G, Gharbia SE, Gulabivala K, Lampert F, Shah HN. The use of 16s rDNA directed PCR for the detection of endodontopathogenic bacteria. J Endod 1997;23:433-8.

144. Siqueira JF, Rôças IN. Diversity of endodontic microbiota revisited. J Dent Res 2009;88:969-81.

145. Noiri Y, Ehara A, Kawahara T, Takemura N, Ebisu S. Participation of bacterial biofilms in refractory and chronic periapical periodontitis. J Endod 2002:28:670-83.

146. Tronstad L, Barnett F, Cervone F. Periapical plaque in teeth refractory to endodontic treatment. Endod Dent Traumatol 1990;6:73-7.

147. O’Toole GA, Pratt LA, Watnick PI, Newman DK, Weaver VB, Kolter R. Genetic approaches to study biofilms. Methods Enzymol 1999;310:91-109.

148. Wolcott RD, Rumbaugh KP, James G, Schultz G, Philips P, Yang Q, Watters C, Stewart PS, Dowd SE. Biofilm maturity studies indicate sharp debridement opens a time-dependant therapeutic window. J Wound Care 2010;19:320-8.

149. Pires D, Sillankorva S, Faustino A, Azeredo J. Use of newly isolated phages for control of Pseudomonas aeruginosa PA01 and ATCC 10145 biofilms. Res Microbiol 2011;162:798-806.

150.Knezevic P, Petrovic O. A colorimetric plate method for assessment of phage effect on Pseudomonas aeruginosa biofilm. J Microbiol Methods 2008;74:114-8.

151. Campos D, Méndez V, Fedotov S. The effects of distributed life cycles on the dynamics of viral infections. J Theor Biol 2008;254:430-8.

152. Azeredo J, Sutherland IW. The use of phages for the removal of infectious biofilms. Cur Pharm Biotechnol 2008;9:261-6.

153.Dixon, B. New dawn for phage therapy. Lancet Infectious Diseases 2004;4:186.

154.Ceri H, Olsen ME, Stremick C, Read RR, Morck D, Buret A. The Calgary biofilm device: New technology for rapid determination of antibiotic susceptibilities of bacterial biofilms. J Clin Microbiol 1999;37:1771-6.

155. Olgart L. Rationalized endodontic treatment by a bacteriological sampling technique. J Dent Res 1970;49:1427-30. 